MASEER

Physics and Mathematics AEC Research and Gevelopment Report

\title{
ROUGHING OF WEAJRRANSER
} SURFACES AS A MEMHOD OF NEREASING TEAT LUX AT BURNOUT PROGRESS REPORI NO I by

W. S. Dur ont and S. Mir shok Pile Engine ting Division PUy $y=195$

E. I. du Pont de Nemours \& Co Sovornoh River laboratory Alken, South Garollina 


\section{DISCLAIMER}

This report was prepared as an account of work sponsored by an agency of the United States Government. Neither the United States Government nor any agency Thereof, nor any of their employees, makes any warranty, express or implied, or assumes any legal liability or responsibility for the accuracy, completeness, or usefulness of any information, apparatus, product, or process disclosed, or represents that its use would not infringe privately owned rights. Reference herein to any specific commercial product, process, or service by trade name, trademark, manufacturer, or otherwise does not necessarily constitute or imply its endorsement, recommendation, or favoring by the United States Government or any agency thereof. The views and opinions of authors expressed herein do not necessarily state or reflect those of the United States Government or any agency thereof. 


\section{DISCLAIMER}

Portions of this document may be illegible in electronic image products. Images are produced from the best available original document. 


$$
D P-380
$$

REACTORS - POWER PHYSICS AND MATHEMATICS

(TID-4500, 14th Ed.)

\author{
ROUGHENING OF HEAT TRANSFER SURFACES AS A \\ METHOD OF INCREASING THE HEAT FLUX AT BURNOUT \\ Progress Report No.1 \\ by
}

William S. Durant and Samuel Mirshak

July 1959

E. I. du Pont de Nemours \& Co.

Explosives Department - Atomic Energy Division

Technical Division - Savannah River Laboratory

Printed for

The United States Atomic Energy Commission

Contract AT $(07-2)-1$

Approved by

J. T. Carleton, Research Manager

Pile Engineering Division 


\begin{abstract}
The heat flux at burnout for rough surfaces that are cooled by forced flow of water in annuli was shown experimentally to be at least 50 to $100 \%$ greater than for smooth surfaces at the same coolant velocity, temperature, and pressure. By roughening the heat transfer surface of a fuel assembly and by increasing the size of the coolant passages, a net galn of as much as $80 \%$ in heat flux at burnout may be realized without increasing the power required to pump the coolant through the assembly. The tests were conducted with electrically heated tubes that were cooled by forced convection bolling of water in annuli surrounding the tubes. The tubes were roughened with knurls or threads to a depth of 0.005 to 0.013 inch.
\end{abstract}




\section{CONTENTS}

$\begin{array}{ll}\text { INTRODUCTION } & 4 \\ \text { SUMMARY } & 4 \\ \text { DISCUSSION } & 4 \\ \quad \text { Background } & 4 \\ \quad \text { Description of equipment and procedure } & 5 \\ \text { Description of test specimens } & 5 \\ \text { Results and calculations } & 6 \\ \text { Discussion of results } & 7 \\ \text { BIBLIOGRAPHY } & 9\end{array}$

\section{LIST OF TABLES AND FIGURES}

Table

I Results of burnout tests 10

II Performance of rough surfaces relative to smooth surfaces

Figure

1

Surface characteristics of a tube with a coarse diamond knurl, 0.008 " deep (Tube 2)

2 Surface characteristics of a tube with a fine diamond knurl, $0.013^{\prime \prime}$ deep (Tube 1)

Surface characteristics of a tube wlth a fine diamond knurl, 0.008" deep (Tube 7)

Surface characteristics of a tube with a fine diamond knurl, 0.005" deep (Tube 6)

Surface characteristics of a tube with 64 threads per inch, 0.009" deep (Tube 3)

Surface characteristics of a tube with 30 threads per inch, 0.006" deep (Tube 4)

Surface characteristics of a tube with a longitudinal knurl, 0:008" deep. (Tube 5) 18

Fanning friction factor for rough surfaces

9 Effect of the friction factor on the burnout heat flux 


\title{
ROUGHENING OF HEAT TRANSFER SURFACES AS A METHOD OF INCREASING THE HEAT FLUX AT BURNOUT
}

Progress Report No.1

\author{
INTRODUCTION
}

In the operation of water-cooled nuclear reactors, the rate of heat transfer from the fuel to the coolant by surface bolling is severalfold higher than that possible with nonbolling heat transfer. If the heat flux is higher than the maximum that can be accommodated by surface bolling, the fuel element wlll operate with fllm bolling of the coolant and with surface temperatures that are higher than the melting point of most cladding materials, and "burnout" wlll occur. Th1s report presents the results of heat transfer experiments that were conducted to determine the extent to which roughening the heat transfer surface will increase the burnout heat flux and the friction factor over those of smooth surfaces.

\section{SUMMARY}

The heat flux at burnout for rough surfaces that are cooled by forced flow of water was experimentally shown to be at least 50 to $100 \%$ greater than for smooth surfaces with the coolant at the same velocity, pressure, and temperature. The friction factors for the rough surfaces were as much as 2.8 times that for smooth surfaces. For the same flow and expenditure of pumping power, the burnout heat flux of rough surfaces is as much as $80 \%$ greater than that of smooth surfaces.

The burnout heat flux was measured in experiments with electrically heated tubes that were cooled by distilled water flowing downward. The coolant flowed in an annulus formed by a glass housing and the outer surface of the heated tube. The heated length of the tubes was 2 feet, and the diameter of the heated surface was $1 / 2$ inch. The surface was roughened mechanically with tools that produced longltudinal knurls (grooves), diamond knurls, and threads to a maximum of $13 \mathrm{mils}$ in depth. The tests were made at a pressure of about 50 psia, and covered a velocity range of 10 to $28 \mathrm{ft} / \mathrm{sec}$ in annul1 that were 0.12 to 0.25 inch thick.

\section{DISCUSSION}

\section{BACKGROUND}

Previous investigations $(1,2)$ have shown that the heat transfer coefficlents in pool bolilng are markedly affected by the roughness of the surface. Corty and Foust $(2)$ found that as the roughness was increased to 0.025 - Inch depth, the temperature difference required to obtain a given heat transfer coefficlent decreased by a factor of 2 . Grass(s) showed that in forced convection heat transfer, the surface roughness can result in a heat transfer coefficient up to 2.7 times that obtained with smooth surfaces. These results were confirmed by 
Averin (1). To the writers' knowledge, Averin was the only investigator who carried his experiments to burnout. He reported that although the heat transfer coefficlent was increased in the early stages of pool bolling, the effect of surface roughness on burnout "ceased to be apparent" in advanced pool bolling and in particular at the "maximum" or burnout heat flux.

\section{DESCRIPTION OF EQUIPMENT AND PROCEDURE}

A detalled description of the equipment and procedure used in the tests is presented in $\mathrm{DP}-355^{(4)}$, and is summarized in the following paragraph.

Distilled water flowed in a closed loop from a pump, through the test section, a heat exchanger, and back to the pump. Direct current was supplied to the test section by elght welding generators connected in parallel with a total rating of about $300 \mathrm{kw}$. The test section consisted primarily of an electrically heated tube which was centered in a glass housing. Water flowed downward through the annulus between the heated tube and the glass housing. The experimental procedure in the burnout runs was to adjust the flow, pressure, and heat flux to predetermined values. The cooling water flow to the heat exchanger was then throttled and the temperature of the coolant through the test section was allowed to increase gradually until burnout occurred.

\section{DESCRIPTION OF TEST SPECIMENS}

The following basic types of surface roughness were evaluated in this study:
1) longl tudinal knurls (grooves)
2) diamond knurls
3) circumferential grooves (threads)

The test specimens were Type 304 stainless steel tubes. The tubes were seamless with a bright annealed finish and had an outside diameter of $1 / 2$ inch wlth a wall thickness of 0.120 inch. The outer surface of the tubes was roughened to a controlled depth by cold working or machining on a lathe. Circumferential grooves were made in the tubes by cutting 30 and 64 threads per inch. The included angle at the base of the grooves was $60^{\circ}$. The knurled surfaces were formed on the tubes with knurling tools of the appropriate shape to form longltudinal knurls and either fine or coarse diamond knurls.

The depth and dimensions of the knurls and threads were obtalned from profilometer tracings and enlarged photographs. Shown in Figures 1 through 7 are the profilometer tracings and photographs of the surfaces of the roughened tubes. 


\section{RESULTS AND CALCULATIONS}

The experimental results are presented in Table I. The coolant temperatures and pressures given are those at the location of the burnout. All the burnouts occurred at the lower end of the two-foot long heated tubes, because the coolant temperature was a maximum and the pressure was a miminum at the lower end.

Also presented in Table I for purposes of comparison are the data on the the burnout heat flux for smooth tubes as presented in DP-355(4). The latter data, whlch were obtained by the same equipment and procedures as those used for rough surfaces, were correlated by the equation:

$$
(\dot{Q} / \mathrm{A})_{\mathrm{BO}}=266,000(1+0.0365 \mathrm{~V})\left(1+0.00914 \mathrm{~T}_{\mathrm{S}}\right)(1+0.0131 \mathrm{P})
$$

where

$$
\begin{aligned}
(Q / A)_{B O} & =\text { heat flux at burnout, pcu/(hr) }\left(\mathrm{ft} t^{2}\right) \\
V & =\text { water velocity, ft/sec } \\
T_{S} & =\text { subcooling, }{ }^{\circ} \mathrm{C} \\
P & =\text { pressure, psia }
\end{aligned}
$$

For computing heat fluxes, the heat transfer area of the rough tube was considered to be the same as that of the smooth tube before machining.

Presented in Figure 8 are the Fanning friction factors as a function of the Reynolds number for each of the tubes that were tested. The friction factors were calculated from pressure drop data for each specimen. The equivalent dlameters for the annull were calculated from the relationship

$$
\text { Equivalent diameter }=4\left(\frac{\text { cross-sectional area for flow }}{\text { wetted perimeter }}\right)
$$

Both the flow area and wetted perimeter were calculated as though the heated tubes were smooth rather than rough. The friction factor increases as the fraction of the total wetted perimeter that is "rough" increases; however, this effect was not evaluated in the present study. From 33 to $40 \%$ of the total wetted perimeter in these tests was rough. The remalning wetted perlmeter was precision-bored glass.

The published ${ }^{(5)}$ friction factors for smooth plpe agreed within $1 \%$ of the measured values for the test annulus, which was formed by an outer surface of glass and an inner surface of smooth tubing. 


\section{DISCUSSION OF RESULTS}

As shown in Table I, the heat flux at burnout for rough surfaces was substantially higher than for smooth surfaces at the same coolant velocity, temperature, and pressure; and was strongly influenced by the type of surface finish. The effect on the burnout heat flux of the different surface finishes is summarized in Table II. This table qualitatively shows that the increase in burnout heat flux is accomplished at the expense of an increased friction factor. Also, the depth of the knurl appears to have a signiflcant effect on the friction factor and burnout heat flux. As the depth of the fine diamond knurl was increased from 5 to $13 \mathrm{mils}$ the friction factor increased from about 1.5 to 2.8 times that of a smooth tube. The burnout heat flux also increased from about 1.4 to as much as 2.1 times that of a smooth tube. The effects of either the depth of groove or the friction factor on the burnout heat flux could not be determined separately because the variables are not separable on the basis of the present data.

A preliminary evaluation indicates that there is no direct correlation between the improvement in the burnout heat flux and the additional surface area produced by roughening, for the range of variables studied. The following table illustrates this fact.

Comparison of Burnout Heat Fluxes and Actual Surface Areas

Ratios Relative to a Smooth Tube

\begin{tabular}{|c|c|c|c|}
\hline $\begin{array}{c}\text { Surface } \\
\text { Treatment } \\
\end{array}$ & $\begin{array}{l}\text { Surface } \\
\text { Area } \\
\end{array}$ & $\begin{array}{c}\text { Burnout Heat Flux* } \\
\text { Based on } \\
\text { Smooth Surface } \\
\end{array}$ & $\begin{array}{c}\text { Burnout Heat Flux } \\
\text { Based on Actual } \\
\text { Surface Areas }\end{array}$ \\
\hline $\begin{array}{l}30 \text { threads/Inch; } \\
0.006^{\prime \prime} \text { deep }\end{array}$ & 1.21 & 1.64 & 1.36 \\
\hline $\begin{array}{l}64 \text { threads/Inch; } \\
0.009 " \text { deep }\end{array}$ & 1.67 & 1.77 & 1.06 \\
\hline $\begin{array}{l}\text { Coarse diamond knurl; } \\
0.008^{\prime \prime} \text { deep }\end{array}$ & 1.30 & 1.52 & 1.17 \\
\hline $\begin{array}{c}\text { F1ne diamond knurl; } \\
0.013^{\prime \prime} \text { deep }\end{array}$ & 1.41 & $1.8-2.1$ & $1.3-1.5$ \\
\hline
\end{tabular}

* Basis is constant veloc1ty, pressure, and subcooling 
The ratio of the burnout heat fluxes of the rough tubes to that of a smooth tube is plotted against the corresponding ratio of friction factors in Figure 9. The graph shows that for a given friction factor, threaded surfaces result in the highest burnout heat flux, followed by the coarse diamond knurl, and the fine diamond knurl.

Although the tube with a longltudinal knurl appears to have a better heat transfer - friction factor characteristic than the fine diamond knurl, the longitudinal knurl is rated below the other surface patterns because of the severe vibration that occurred when it was tested. Vibration is known to improve the heat transfer coefficlent, and occurred only in runs with the longltudinal knurl. It is believed that the vibration was the primary cause of the 1mproved heat transfer, rather than the roughness. Visual observations of the test specimens during the runs indicated that the vapor being formed on the heated surface was rising in the grooves on the tube surface. The vapor columns appeared to osclilate as they progressed up the annulus. It is hypothesized that the upward flowing vapor was condensed by the downward flowing water and the resulting pulses set up the vibration as the condensed vapor reversed direction and flowed downward.

As shown in Table II, rough surfaces permit substantial increases in the burnout heat flux without increasing the pumping power. The last column in the table is a comparison of the burnout heat flux of the rough surfaces to the burnout heat flux of a smooth surface at the same flow and pressure drop. Because of the higher head loss across rough surfaces, the coolant velocity must be reduced and the equivalent diameter of the coolant channel increased correspondingly if the pumping power and flow are to remain the same as for a smooth surface. For turbulent flow in thin annuli*, it follows from the Fanning equation for friction loss that the velocity for a rough surface is inversely proportional to the cube root of the friction factors. If the subcooling and pressure at the burnout site are held constant, the ratio of the burnout heat flux for a rough surface to that of a smooth surface at constant flow and head loss is obtained by substituting in Equation (I) as follows:

$$
\left[\frac{(\mathrm{Q} / \mathrm{A})_{\mathrm{BO}_{\mathrm{r}}}}{(\mathrm{Q} / \mathrm{A})_{\mathrm{BO}_{\mathrm{S}}}}\right]_{\Delta \mathrm{P}, \mathrm{F}}=\left[\frac{1+0.0365 \mathrm{~V}_{\mathrm{S}} \sqrt[3]{\left(\frac{\mathrm{f}_{\mathrm{S}}}{\mathrm{f}_{\mathrm{r}}}\right)}}{\left(1+0.0365 \mathrm{~V}_{\mathrm{S}}\right)}\right]\left[\frac{(\mathrm{Q} / \mathrm{A})_{\mathrm{BO}}}{(\mathrm{Q} / \mathrm{A})_{\mathrm{BO}}}\right] \mathrm{V}
$$

* A thin annulus is one in which the velocity is inversely proportional to the equivalent diameter. 
where $(Q / A)_{B O}$ is the heat flux at burnout, $f$ is the friction factor, $V$ is the velocity in $\mathrm{ft} / \mathrm{sec}$, s refers to the smooth surface, and $r$ refers to the rough surface. The subscripts $\Delta P$ and $F$ refer to operation at constant head loss and flow, whlle the subscript $V$ refers to constant velocity.

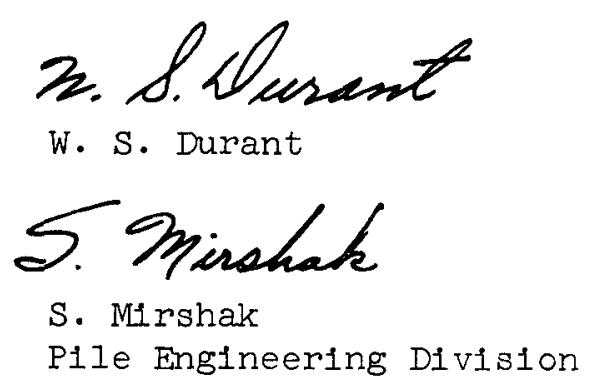

\section{BIBLIOGRAPHY}

1. Averin, E. K. Izvest. Akad. Nauk S.S.S.R. Otdel. Tech. Nauk, No. 3, pp 116-122 (1954) Atom1c Energy Research Establishment, Harwell, Berks. AERE. Lib/Trans. 562.

2. Corty, C. and Foust, A. S. Ann. Meeting Am. Inst. Chem. Engrs. St. Louis, Preprint No. I (1953).

3. Grass, Gunther. Atomkernenergie 3, 328-331 (1958).

4. Mirshak, S., Durant, W. S., and Towell, R. H. Heat Flux at Burnout, E. I. du Pont de Nemours and Co., DP-355, February 1959.

5. Perry, J. H., Chemical Engineer's Handbook, 3d.Ed., New York: McGraw - H1ll, p. 377-382, 1950. 
TABLE I

\section{RESULTS OF BURNOUT TESTS}

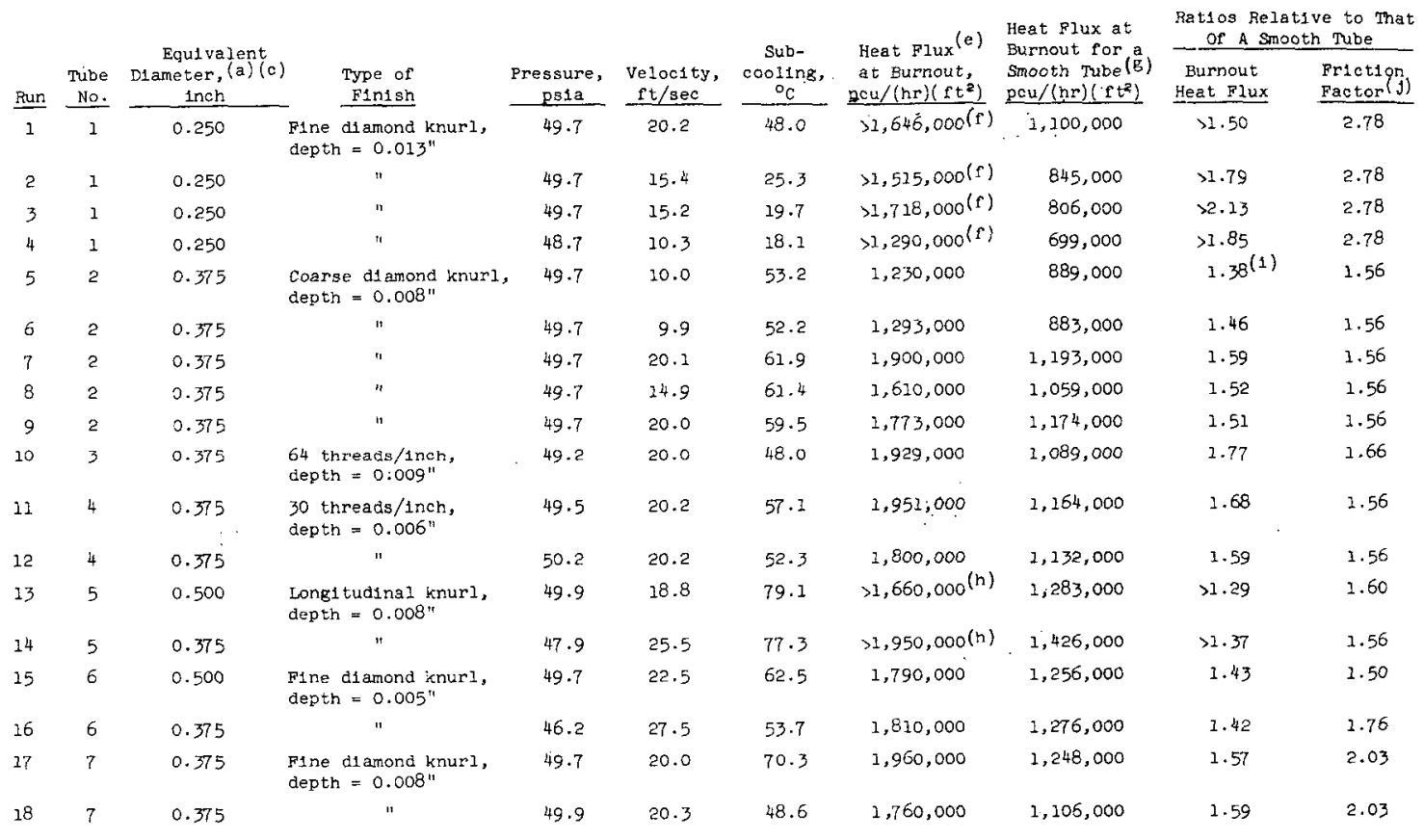

(b) Nominal, diameter of heated surface $=0.50 \mathrm{2nch}$

(c) Heated length $=24$ inches

(d) Heated material is Type 304 stainless steel

(e) Heat flux referred to area of a smooth tube $1 / 2$ inch in diameter

(f) Experiment terminated before burnout because of equipment limitations

(g) Calculated from Equation (1) for velocity, pressure, and subcooling as listed in the table

(h) Runs terminated before burnout because of severe vibration of heated tube during advanced bolling

(1) Burmout occurred prematurely because of a local flaw in specimen. The flaw was found in post examination

(j) Friction factor evaluated at Reynolds number of 62,000 


\section{PERFORMANCE OF ROUGH SURFACES RELATIVE TO SMOOTH SURFACES}

\begin{tabular}{|c|c|c|c|c|}
\hline Thube & Surface Treatment & $\begin{array}{l}\text { Rat1o of Burnout Heat } \\
\text { Flux of Rough Tube to } \\
\text { That of a Smooth Tube (a) (a) }\end{array}$ & $\begin{array}{l}\text { Ratio of Friction } \\
\text { Factor of a Rough } \\
\text { Tube to That of } \\
\text { a Smooth Tube (b)?d) }\end{array}$ & $\begin{array}{l}\text { Ratio of the Burnout } \\
\text { Heat Flux of a Rough } \\
\text { Tube to That of } \\
\text { a Smooth Tube (c) } \\
\end{array}$ \\
\hline & Smooth (Ref. 5) & I & 1 & 1 \\
\hline 2 & $\begin{array}{l}\text { Coarse diamond knurl, } \\
0.008 \text { " deep }\end{array}$ & 1.52 & 1.56 & 1.42 \\
\hline 6 & $\begin{array}{l}\text { Fine diamond knurl, } \\
0.005^{11} \text { deep }\end{array}$ & 1.42 & 1.63 & 1.32 \\
\hline 7 & $\begin{array}{l}\text { Fine diamond knurl, } \\
0.008 \text { " deep }\end{array}$ & 1.58 & 2.03 & 1.42 \\
\hline 1 & $\begin{array}{l}\text { Fine diamond knurl, } \\
0.013^{11} \text { deep }\end{array}$ & $>1.80-2.10$ & 2.78 & $>1.55-1.80$ \\
\hline 5 & $\begin{array}{l}\text { Longl tudinal knurl, } \\
0.008 \text { " deep }\end{array}$ & $>1.30-1.40$ & 1.58 & $>1.21-1.30$ \\
\hline 4 & $\begin{array}{l}30 \text { threads/1nch, } \\
0.006 " \text { deep }\end{array}$ & 1.64 & 1.56 & 1.53 \\
\hline 3 & $\begin{array}{l}64 \text { threads/inch, } \\
0.009 \text { " deep }\end{array}$ & 1.77 & 1.66 & 1.64 \\
\hline
\end{tabular}

(a) Compared at same velocity, pressure, and subcooling

(b) Compared at a Reynolds number of 62,000 for 1sothermal flow through annull

(c) Compared at same flow, head loss, subcooling, and pressure

(d) Results do not account for any reduction in burnout heat flux or friction factor caused by changes in equivalent diameter required to maintain the same pressure drop 



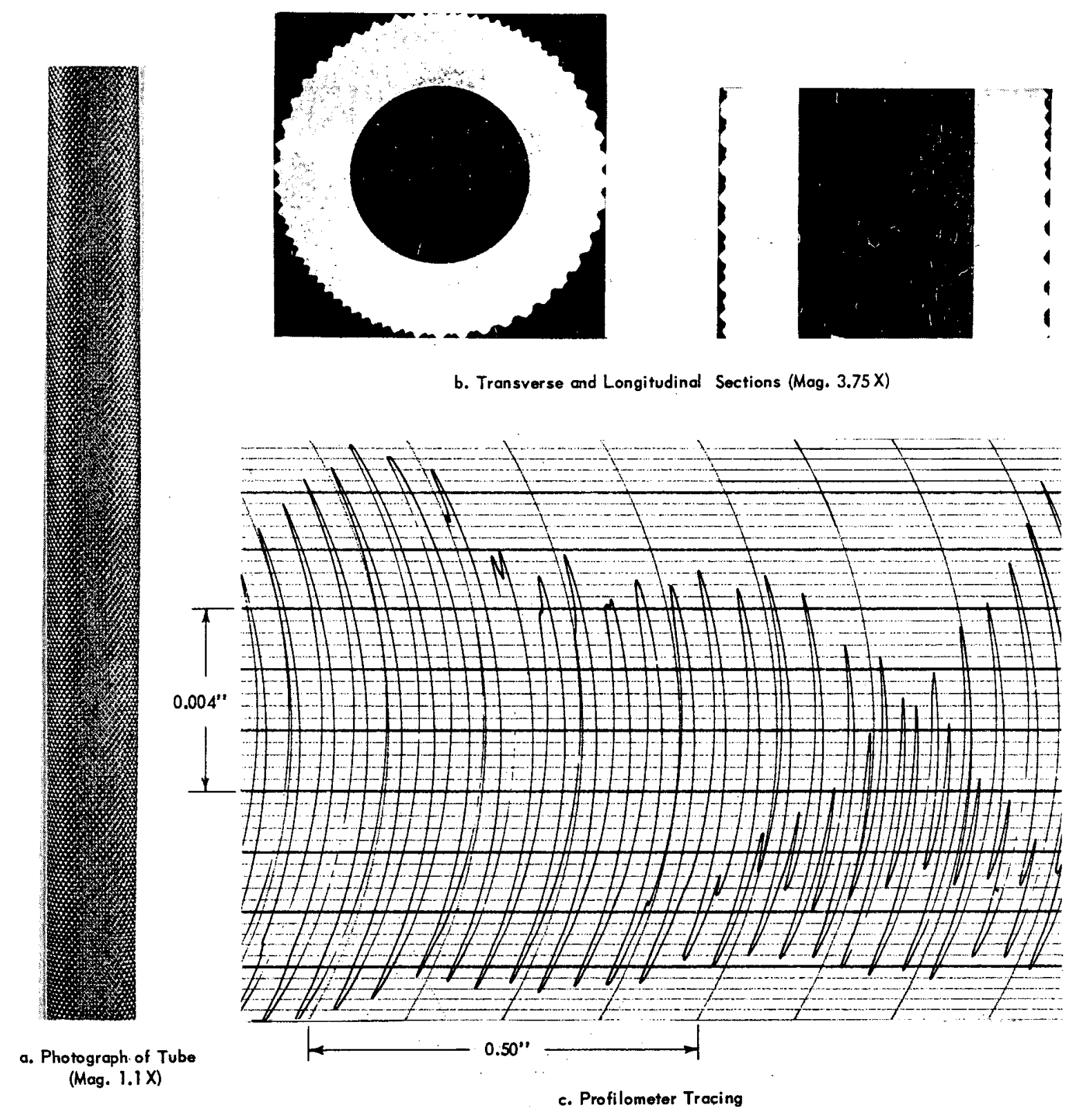

FIGURE 2 - SURFACE CHARACTERISTICS OF A TUBE WITH A FINE DIAMOND KNURL, $0.013^{\prime \prime}$ DEEP (Tube I) 

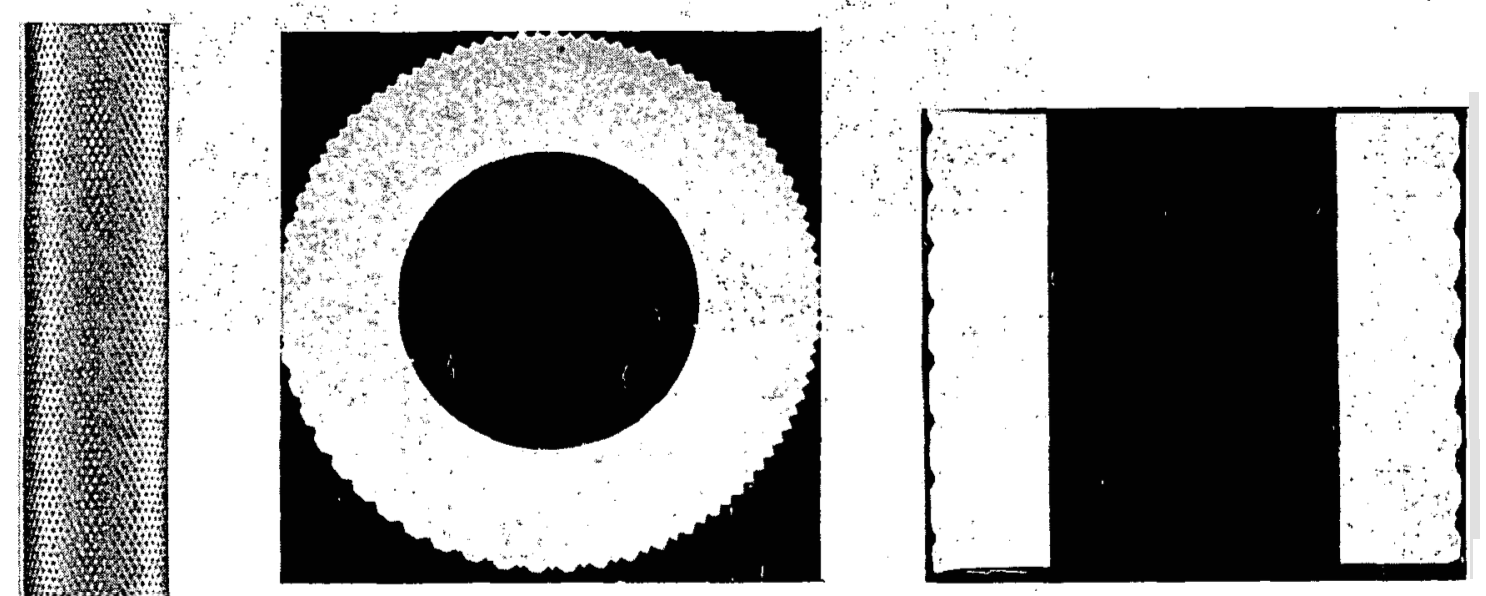

b. Transverso and Longitudinal Soctions (Mag. $4.3 x$ )

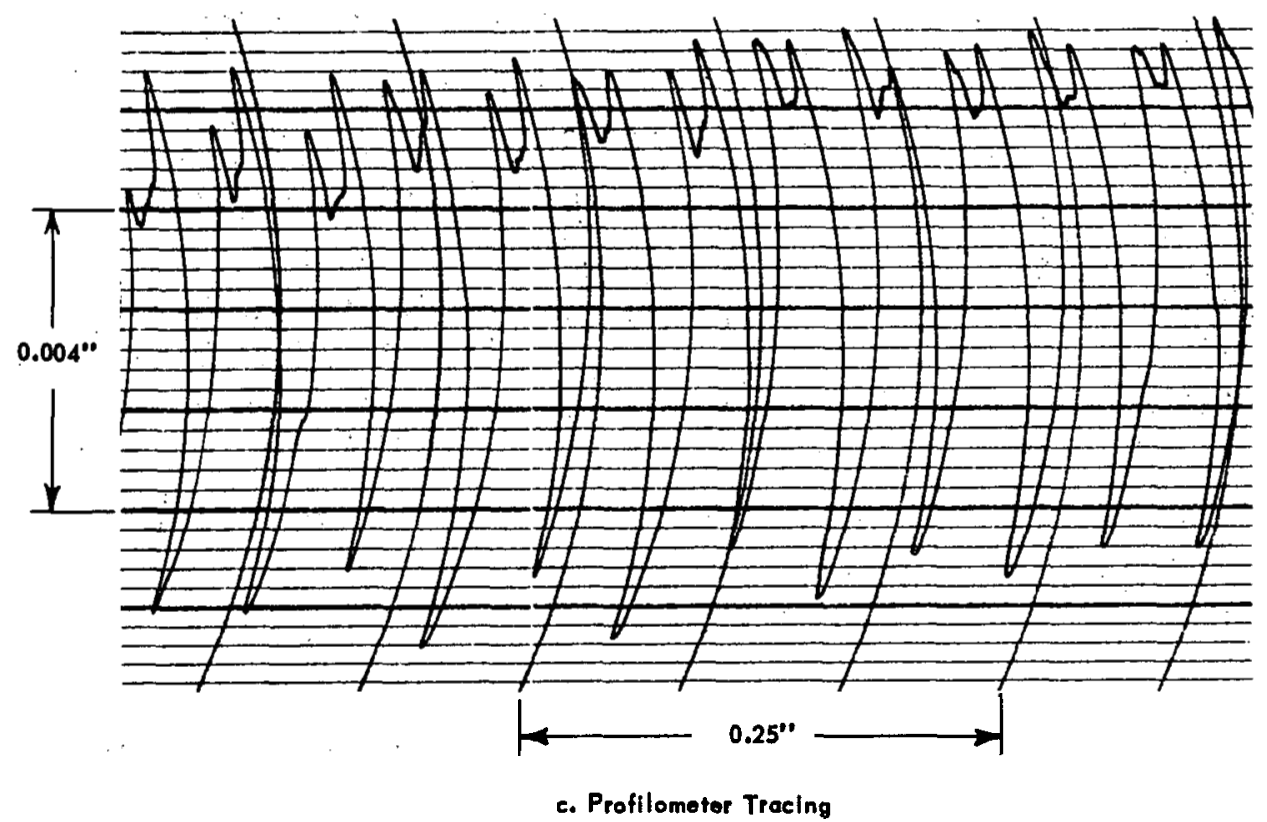

a. Photograph of Tube

(Mog. 1.2X)

FIGURE 3 - SURFACE CHARACTERISTICS OF A TUBE WITH A FINE DIAMOND KNURL, 0.008" DEEP (Tube 7 ) 

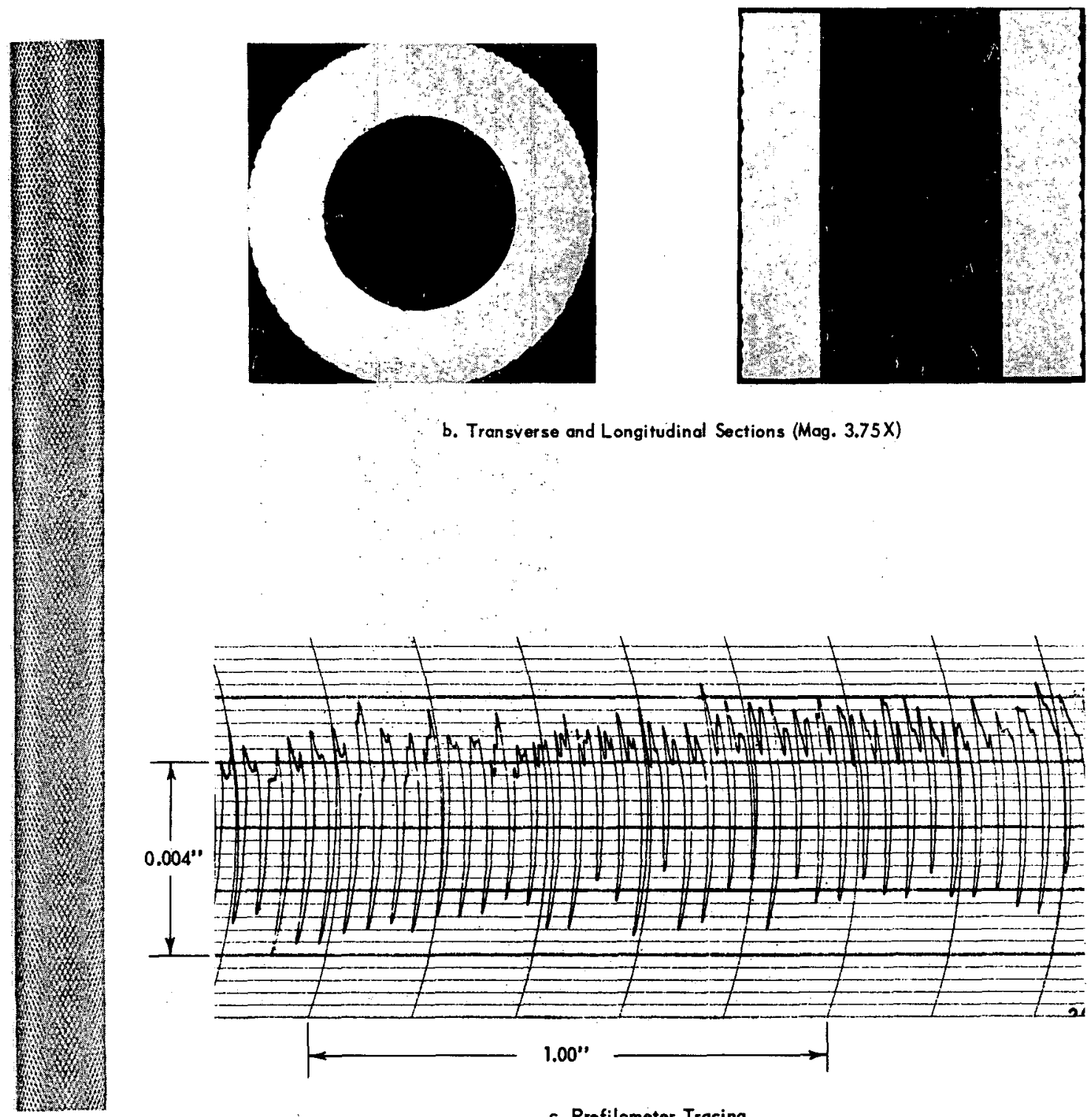

b. Transverse and Longitudinal Sections (Mag. 3.75X)

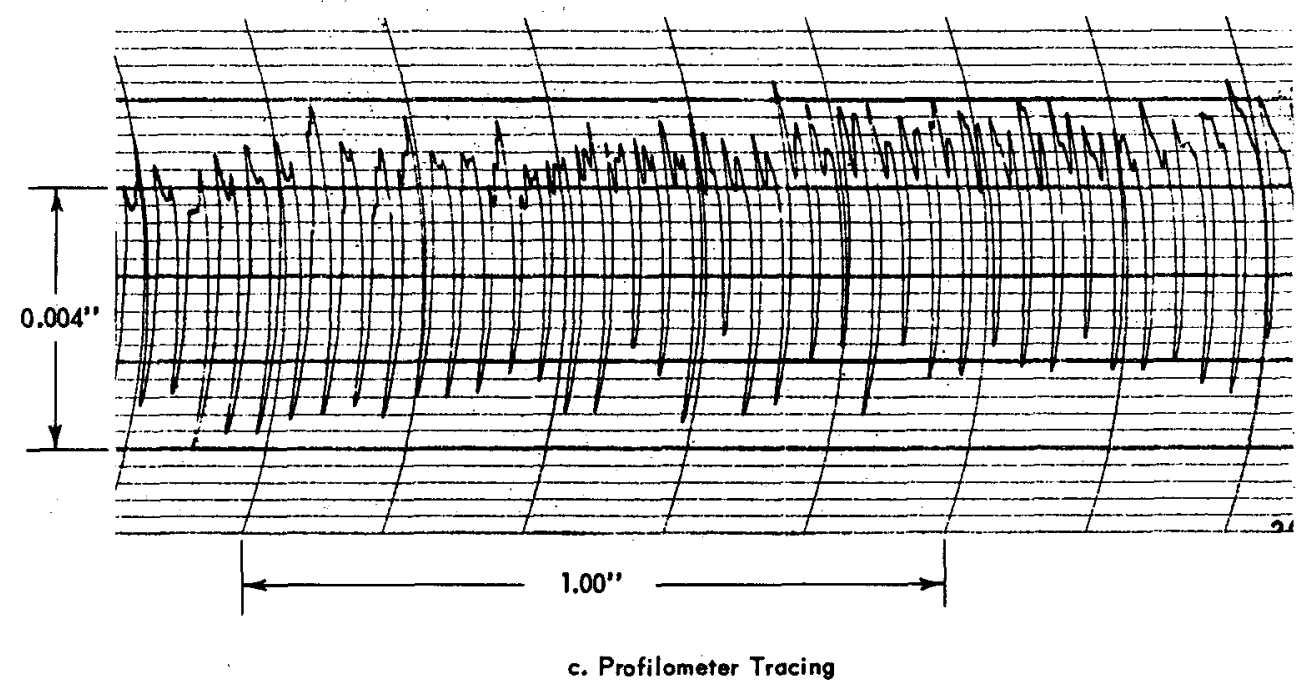

a. Photograph of Tube

(Mog. 1X)

FIGURE 4 - SURFACE CHARACTERISTICS OF A TUBE WITH A FINE DIAMOND KNURL, 0.005" DEEP (Tube 6) 

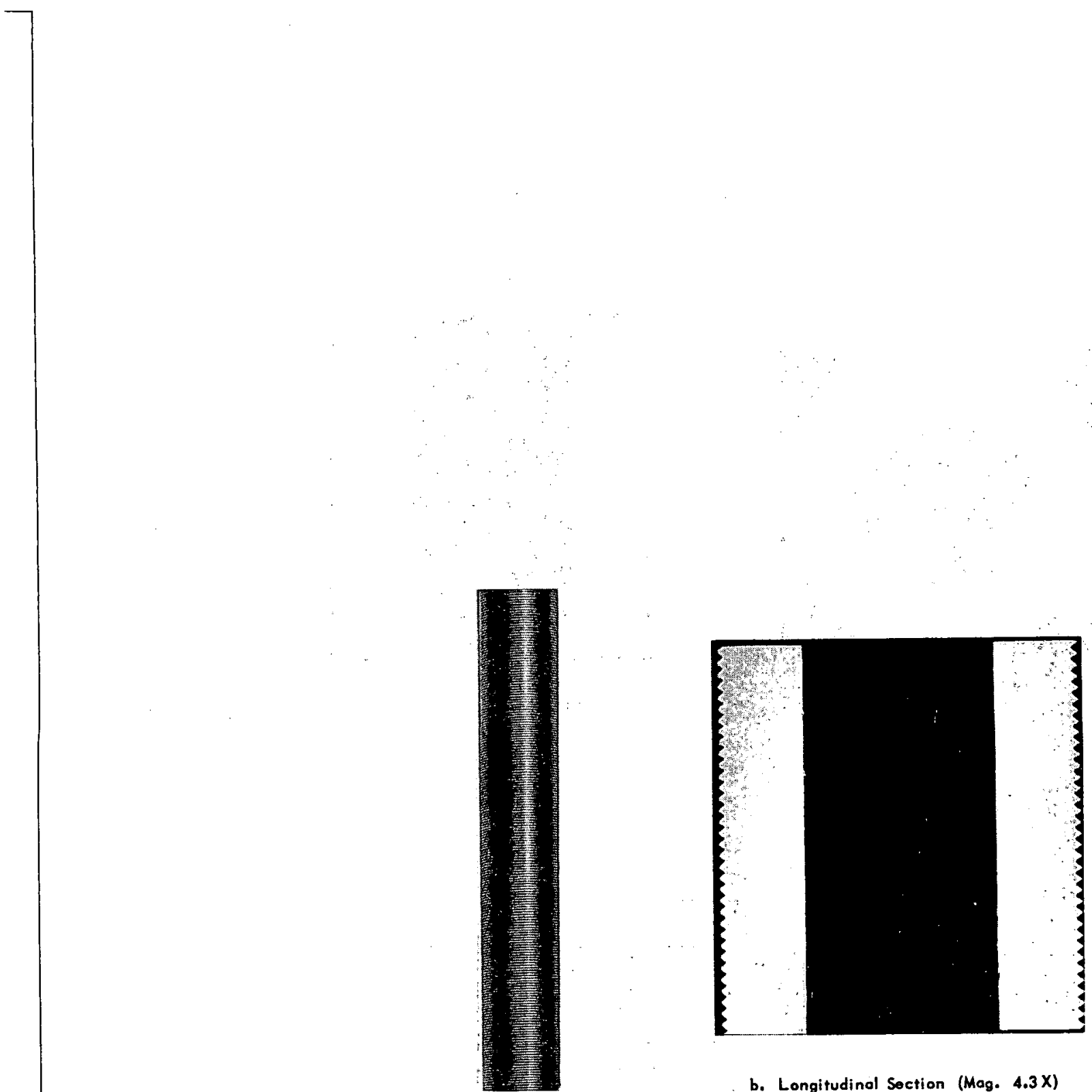

b. Longitudinal Soction (Mag. $4.3 \mathrm{X}$ )

a. Photogroph of Tube

(Mog. I X)

FIGURE 5 - SURFACE CHARACTERISTICS OF A TUBE WITH 64 THREADS PER INCH, 0.009" DEEP (Tube 3) 


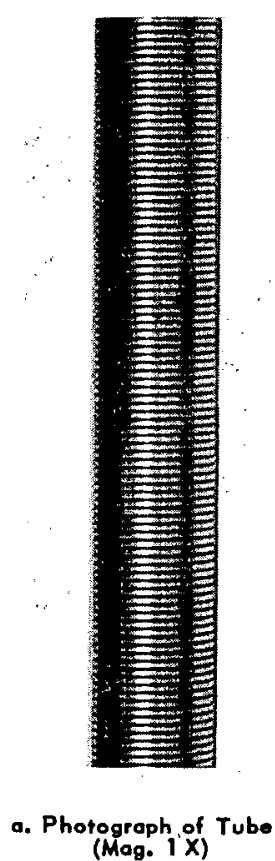

(Mog. I X)

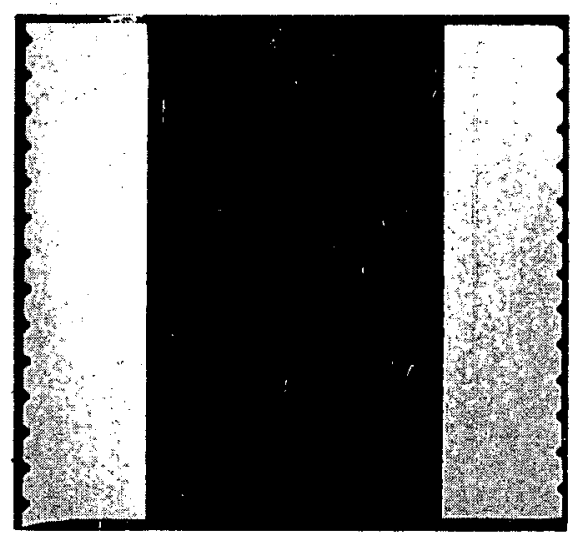

b. Longitudinal Soction (Mag. $4.3 \mathrm{X}$ )

FIGURE 6 - SURFACE CHARACTERISTICS OF A TUBE WITH 30 THREADS PER INCH, 0.006" DEEP (Tube 4) 


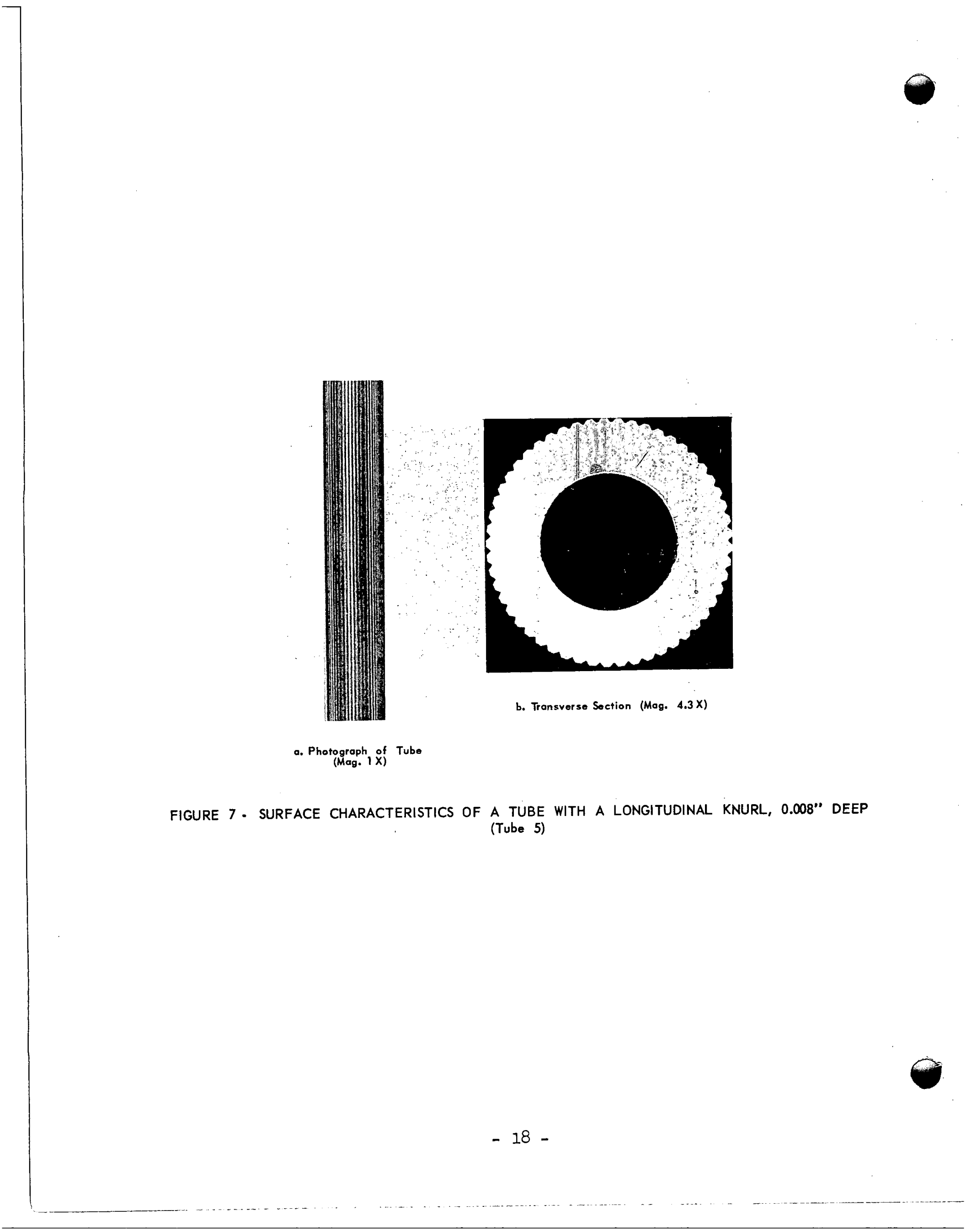




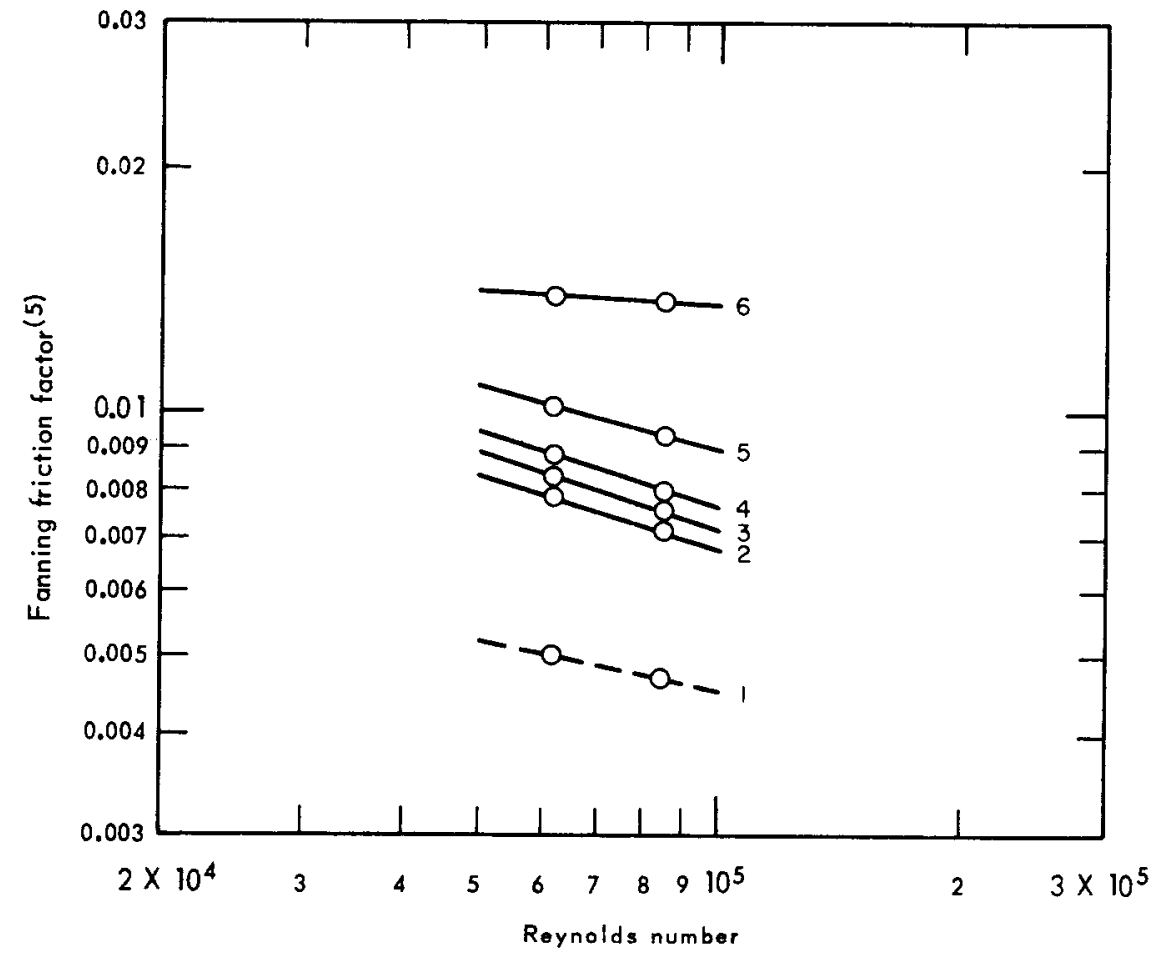

Data for annular geometry with glass tube forming the outer surface and rough tub

forming the inner surface

- - Published friction factor $(5)$ for flow inside smooth pipes

$\begin{array}{crr}\text { Curve } & & \text { Tube } \\ 1 & & \text { Ref } \\ 2 & & 5 \\ 2 & 2 \\ 2 & 4 \\ 3 & 3 \\ 4 & 6 \\ 5 & 7 \\ 6 & 1\end{array}$

Treatment
Smooth
Longitudinal knurl
Coarse diamond knurl
30 Threads per inch
64 Threads por inch
Fine diamond, 0.005 "' doep
Fine diamond, 0.008 ", deep
Fine diamond, 0.013 "' deep

Equivalent diameter, in.

0.250

0.375

0.375

0.375

0.375

0.375

0.375

0.250

FIGURE 8 - FANNING FRICTION FACTOR FOR ROUGH SURFACES 


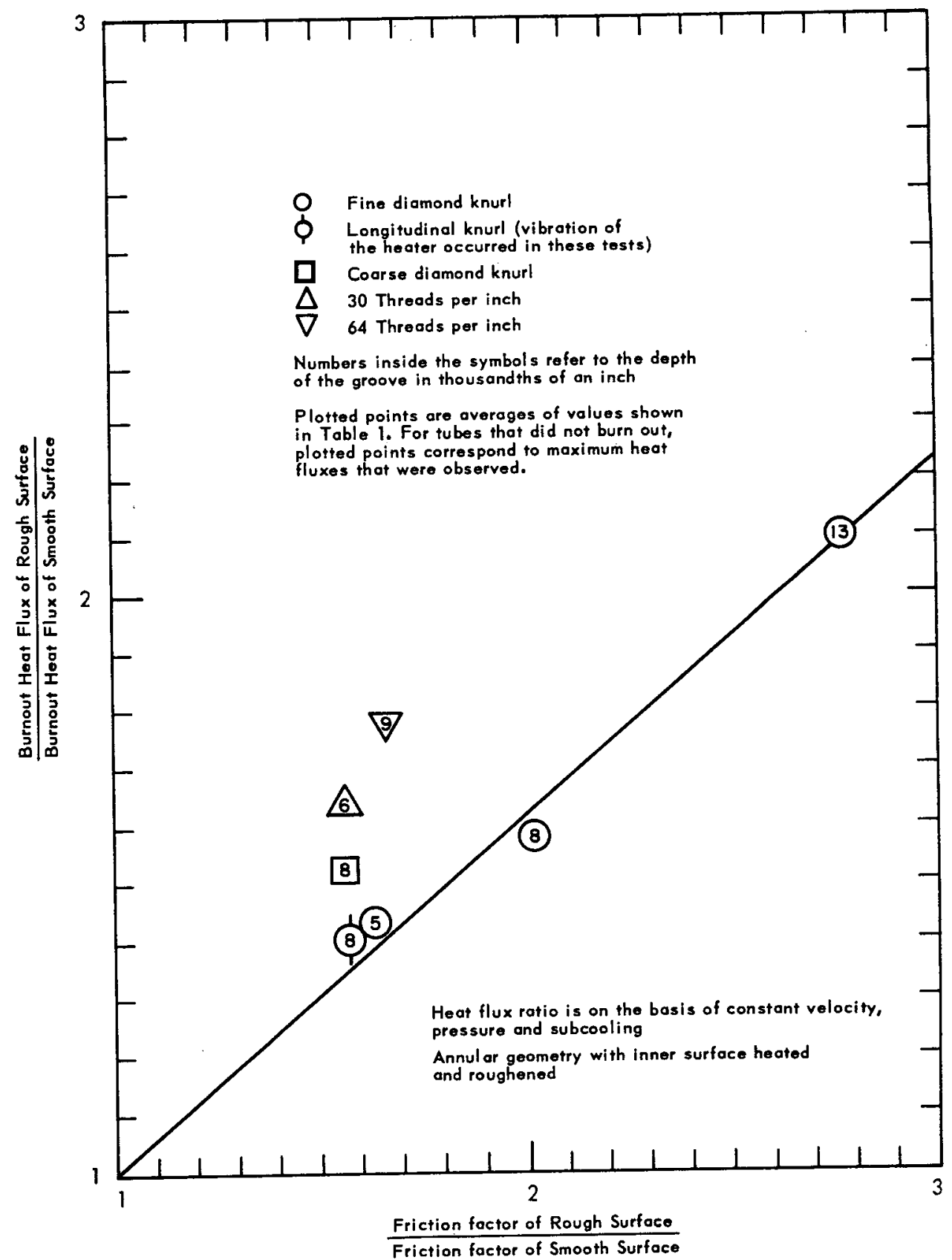

FIGURE 9 - EFFECT OF THE FRICTION FACTOR ON THE BURNOUT HEAT FLUX 